\title{
Statistical Design and Optimization of Sustained Release Formulations of Pravastatin
}

\section{Pravastatinin Uzatılmış Salım Formülasyonlarının İstatistiksel Tasarım Kullanılarak Geliştirilmesi ve Optimizasyonu}

\author{
(D) Raghavendra Kumar GUNDA ${ }^{*}$, (D) Prasada Rao MANCHINENI2 \\ 1 MAM College of Pharmacy, Department of Pharmaceutics, Andhra Pradesh, India \\ 2MAM College of Pharmacy, Department of Pharmaceutical Analysis, Andhra Pradesh, India
}

\begin{abstract}
Objectives: The objective of the current study was to formulate a sustained release (SR) formulation for pravastatin. Pravastatin is a lipid lowering, biopharmaceutical classification class-III agent.

Materials and Methods: SR tablets of pravastatin were prepared using variable amounts of hydroxy methyl propyl cellulose (HPMC) K4M and sodium carboxy methyl cellulose in various proportions by direct compression in a $3^{2}$ factorial design. The amounts of the polymers HPMC K4M and sodium carboxy methyl cellulose required to obtain prolonged release of drug were chosen as independent variables, $X_{1}$ and $X_{2}$, respectively, whereas times taken for $10 \%, 50 \%, 75 \%$, and $90 \%$ drug release were chosen as dependent variables.

Results: Nine formulations were developed and were checked using pharmacopoeial tests. The results showed that all the factorial batches were within the standard limits. The dissolution parameters of all formulations were subjected to kinetic fitting and various statistical parameters were determined. Polynomial equations were developed and verified for dependent variables. Formulation $\mathrm{F}_{5}$, containing 25 mg of HPMC K4M and 25 $\mathrm{mg}$ of sodium carboxy methyl cellulose, was the formulation most similar (similarity factor $f_{2}=89.559$, difference factor $f_{1}=1.546$ ) to the marketed product (Pravachol).
\end{abstract}

Conclusion: The best formulation $\left(F_{5}\right)$ follows Higuchi's kinetics and non-Fickian diffusion zero order kinetics $(n=1.083)$.

Key words: Pravastatin, sustained release tablet, HPMC K4M, $3^{2}$ factorial design, zero order kinetics, non-Fickian diffusion mechanism

ÖZ

Amaç: Bu çalışmanın amacı, biyofarmasötik sınıflandırma sistemi III grubunda yer alan lipit düșürücü etkili pravastatinin sürekli salım yapan formülasyonunun geliștirilmesidir.

Gereç ve Yöntemler: Pravastatin'in sürekli salım tabletleri, direkt kompresyonla $3^{2}$ faktöryel tasarıma göre çeşitli oranlarda hidroksi metil propil selüloz (HPMC) K4M ve sodyum karboksi metil selüloz kullanılarak hazırlanmıștır. Pravastatin'in uzun süreli salınımını elde etmek için bağımsız değișkenler olarak HPMC K4M $\left(X_{1}\right)$ ve sodyum karboksi metil selüloz $\left(X_{2}\right)$ miktarları; \%10, \%50, \%75 ve \%90 ilaç salımı için geçen süreler ise bağımlı değişkenler olarak seçilmiştir.

Bulgular: Dokuz formülasyon geliștirilmiș ve bu formülasyonlara farmakopede belirtilen kontrol testleri uygulanmıştır. Sonuçlar geliștirilen tüm formülasyonların standart limit değerler arasında olduğunu göstermiştir. Tüm formülasyonların disolüsyon parametreleri kinetik modellere uygulanarak çeşitli istatistiksel parametreler belirlenmiştir.

Polinomiyal denklemler bağımlı değişkenler için geliştirilmiş ve doğrulanmıştır. 25 mg HPMC K4M ve 25 mg sodyum karboksimetil selüloz içeren formülasyondan $\left(F_{5}\right)$ pravastatin salımı, ticari preparatı (Pravachol) ile benzer bulunmuştur (benzerlik faktörü $f_{2}=89,559$; fark faktörü $f_{1}=1,546$ ).

Sonuç: En iyi formülasyonunun $\left(F_{5}\right)$, Higuchi kinetiği, Fick kanununa uymayan difüzyonun sıfırıncı derece kinetiğine $(n=0,864)$ uygun davranış gösterdiği bulunmuștur.

Anahtar kelimeler: Pravastatinin, sürekli salım tableti, HPMC K4M, $3^{2}$ faktöriyel tasarım, sıfırıncı derece kinetik, Fick kanununa uymayan difüzyon mekanizması

*Correspondence: E-mail: raghav.gunda@gmail.com, Phone: +91 9666705894 ORCID-ID: orcid.org/0000-0002-4271-8614

Received: 03.12.2018, Accepted: 07.02.2019

-Turk J Pharm Sci, Published by Galenos Publishing House. 


\section{INTRODUCTION}

Enteral delivery is an effective, popularly used mode of administration for both immediate and new drug delivery systems. In the case of chronic therapy, immediate release dosage forms are administered in a repetitive manner, resulting in more problems.' The majority of these drugs undergo the first pass effect or presystemic elimination, which results in poor bioavailability and shorter activity.

Sustained release (SR) formulations show constant $C_{\text {ss }}$ levels for a prolonged period, decreased dosing frequency, and patient compliance. ${ }^{2}$ Zero-order drug release from the formulation will aid the $\mathrm{C}_{\mathrm{ss}}$ constantly for a longer period. Zero-order kinetics is one of the aims of SR forms. ${ }^{2,3}$

Polymers were utilized for achieving sustained drug release. The literature reveals that utilization of polymers plays a key role in pharmaceutical product development. ${ }^{4}$

Natural polymers remain preferred due to their numerous advantages. Extensively used natural gums include xanthan gum, guar gum, tragacanth gum, and alginates. Cellulosics like hydroxy methyl propyl cellulose (HPMC), hydroxy propyl cellulose, carboxy methyl cellulose (CMC), and sodium (S) CMC belong to the semisynthetic category and have been extensively studied in SR tablet formulations. ${ }^{5}$

Direct compression is a widely used manufacturing method for the preparation of tablets. ${ }^{6}$ The current research experimentation focuses on the design of a SR formulation for pravastatin.

Pravastatin, a potent hypolipidemic agent, belongs to biopharmaceutical classification class-III. It is a specific inhibitor (competitive) of HMG CoA. Pravastatin is useful for the effective management of atherosclerotic vascular disease. It undergoes an extensive first pass effect in the liver. Its bioavailable fraction is 0.17 , about $50 \%$ of protein binding (plasma proteins). The elimination half-life for pravastatin is 1.5-2 $\mathrm{h}$ and it is eliminated from the body via feces and urine. Hence, research work was planned to formulate and evaluate SR tablets for pravastatin as a model drug and had the objective that the optimized formulation trial should show desired SR of the drug by means of an enhanced dissolution rate..$^{7-14}$

Response surface methodology (RSM) with a polynomial equation has been extensively applied in the design and development of pharmaceutical products. Variations of RSM include $3^{2}$ factorial design, central composite design, and BoxBehnken design. RSM is applied when only a few significant factors are involved in the optimization procedure. The advantage of this method is less experimentation and time, the results are more effective, and it is more cost effective than tradition experimentation models. ${ }^{15-18}$

Hence an attempt was made in the present research work to formulate SR tablets of pravastatin using HPMC K4M and SCMC. Instead of a heuristic method, a standard statistical tool design of experiments was used to study the effect of formulation variables on the release properties.

A $3^{2}$ factorial design was used to study the effect of polymers on the drug release profile (effect of independent variables or factors), i.e. the quantity of HPMC K4M and SCMC, on the dependent variables $\left(t_{10 \%}, t_{50 \%}, t_{75 \%}, t_{90 \%}\right){ }^{19}$

\section{MATERIALS AND METHODS}

The materials used in the research were procured from various sources. Pravastatin was a gift sample from Konis Pharma Ltd, Baddi, India. HPMC K4M, SCMC, and lactose were obtained from Meditech Pharma Ltd, Solan. Magnesium stearate, talc, and lactose obtained from Loba Chemie Pvt. Ltd, Bombay.

\section{Formulation and development of SR pravastatin tablets}

Quantities required for the HPMC K4M and SCMC for the preparation of SR pravastatin tablets were selected as independent variables. $t_{10 \%}, t_{50 \%}, t_{75 \%}$, and $t_{90 \%}$ were selected as dependent variables. Polynomial equations were developed for dependent variables as per backward stepwise linear regression analysis. ${ }^{20,21}$

The 3 levels of $X_{1}$ (HPMC K4M) were $7.5 \%, 12.5 \%$, and $17.5 \%$. The 3 levels of $X_{2}$ (SCMC) were $7.5 \%, 12.5 \%$, and $17.5 \%$ (\% with respect to average weight of tablet). Nine SR pravastatin tablet formulations were designed using selected combinations of $X_{1}$ and $X_{2}$ and checked for the selection of the optimum composition required to meet the primary objective of the study.

\section{Preparation of SR pravastatin tablets}

All the ingredients were procured and weighed accurately. They were mixed uniformly in a poly bag for 10-15 min. The resulting mix was subjected to screening (\#44). Lubricant was added, followed by mixing well and then compression using a tablet compressor. The resulting tablets were checked in terms of pharmacopoeial limits. The tablets were packed in well-closed air-tight containers.

\section{Experimental design}

The experimental design used in the current research was a $3^{2}$ factorial design; the quantity of HPMC K4M was labeled $X_{1}$ and the quantity of SCMC was labeled $X_{2}$ and they are presented in Table 1. The 3 levels chosen for both $X_{1}$ and $X_{2}$ were coded as $-1=7.5 \%, 0=12.5 \%$, and $+1=17.5 \%$. The formulations for the factorial trials are presented in Table 2.

\section{Evaluation of SR pravastatin tablets}

\section{Hardness}

This test was performed with the help of a Monsanto hardness tester.

\section{Friability}

This test was carried out in a Roche friabilator. The initial weight $\left(\mathrm{W}_{0}\right)$ of 20 tablets was noted and then they were dedusted in a drum with a speed of $25 \mathrm{rpm}$ for $4 \mathrm{~min}$ and weighed (W) again. Percentage friability was calculated using the following equation. The weight loss should not be more than $0.8 \%$.

Friability $(\%)=[(w o-w) / w] \times 100$

\section{Assay}

This test was carried out by taking a fixed number of samples (20) and subjecting them to pulverization. From that above resultant 
mixture powder equivalent to $100 \mathrm{mg}$ was dissolved in 100 $\mathrm{mL}$ of solvent (6.8 buffer) and sonicated if necessary followed by filtration. The absorbance of the resultant solution was measured using a ultraviolet (UV)-Visible spectrophotometer at $239 \mathrm{~nm}^{15}$

\section{Thickness}

This test was performed with the help of vernier calipers.

\section{In vitro dissolution study}

Dissolution tests were performed using the USP Apparatus 2. The specifications were followed as per official methods such as dissolution medium for initial $2 \mathrm{~h}$ is $900 \mathrm{~mL}$ of $\mathrm{pH} 1.2$ buffer followed by $\mathrm{pH} 6.8$, at $50 \mathrm{rpm}$ and $37 \pm 0.5^{\circ} \mathrm{C}$. Samples were collected at fixed time intervals by a pre-filter connected syringe and replacement of fresh fluid was done simultaneously. The absorbance of samples was measured at $239 \mathrm{~nm}$ using a Labindia UV-3200 UV-Visible spectrophotometer $(n=3)$. 9,12,14

\section{Kinetic modeling of drug release}

The kinetic data were subjected to statistical modeling, i.e. zero order, first order, Higuchi, and Korsmeyer-Peppas kinetics. ${ }^{22,23}$ The study did not require ethics committee approval or patient informed consent because it did not focus on any clinical parameter and did not utilize any humans/animals for the processing of work.

\section{RESULTS AND DISCUSSION}

SR tablets of pravastatin were formulated with the help of a $3^{2}$ factorial design for identifying the optimized composition of polymers (HPMC K4M and SCMC) and to obtain prolonged/ sustained drug release from the formulation. The experimental design is presented in Table 1. The 2 factors involved in the design of formulations are quantity of HPMC K4M and SCMC, which were labeled as independent variables $\left(X_{1}, X_{2}\right)$, while kinetic parameters were labeled as dependent variables $\left(t_{10 \%}\right.$, $\left.t_{50 \%}, t_{75 \%}, t_{90 \%}\right)$. Nine factorial batches were designed and all trials had $40 \mathrm{mg}$ of pravastatin as a SR tablet dosage form by direct compression technique as per the formulae given in Table 2.

All final batches were subjected to various final product quality assurance tests like mean hardness, mean thickness, friability, weight variation, and drug content, and the results are summarized in Table 3. Hardness for finished batches was in the range of $3.47 \pm 0.3-4.10 \pm 0.5 \mathrm{~kg} / \mathrm{cm}^{2}$. Thickness for finished batches was in the range of $2.45 \pm 0.15-2.86 \pm 0.14 \mathrm{~mm}$. Results for the friability test were less than $0.51 \%$. Drug content for finished batches met the acceptance criterion. Drug release studies were performed for finished batches using $\mathrm{pH} 1.2$ buffer for an initial 2 hour followed by phosphate buffer $\mathrm{pH} 6.8$ as operated under a standard set of conditions at $50 \mathrm{rpm}$ (paddle), $37 \pm 0.5^{\circ} \mathrm{C}$. Dissolution plots are presented in Figures 1-4 (kinetic plots) and the statistical parameters are summarized in Table 4. \% percentage cumulative drug release for finished batches $\mathrm{F}_{1}-\mathrm{F}_{9}$ at 12 hour was $88.88-99.61 \%$. The result revealed that the release rate of drug was inversely proportional to the quantity of polymers. Hence the desired drug release was achieved by manipulating values of independent variables. A difference was seen in dependent variables due to change in proportions of $X_{1}$ and $X_{2}$. Formulation coded $F_{5}$ containing $25 \mathrm{mg}$ of HPMC K4M and $25 \mathrm{mg}$ of SCMC produced desirable release characteristics $\left(t_{10 \%}=0.459 h, t_{50 \%}=3.025 h, t_{75 \%}=6.040 h, t_{90 \%}=10.045 h\right)$, which was probably due to variation in the viscosity of the polymer matrix. An increase in the viscosity of the stagnant layer results in a corresponding decrease in drug release (due to thicker gel layer formation). ${ }^{24}$ The dissolution profiles of SR pravastatin tablets were subjected to kinetic modeling. The results are presented in Table 4 and Figures 1-4. The results reveal that all formulation batches best fitted zero order kinetics and $r^{2}$ was in the range of 0.995-0.999. They also fitted Higuchi's kinetics; $r^{2}$ was in the range of $0.941-0.968$. The Peppas treatment revealed that all batches follow a non-Fickian diffusion path ( $n$ values 1.046-1.397). Polynomial equations were developed for all dependent variables by linear stepwise backward regression analysis with the help of PCP Disso software and response morphological plots were constructed using SigmaPlot V13. The response morphological plots are presented in Figures 5 -8 for $t_{10 \%}, t_{50 \%}, t_{75 \%}$, and $t_{90 \%}$ using $X_{1}$ and $X_{2}$ on both axes to show the effects of independent variables on the dependent variables. Kinetic parameters for the trials $\left(\mathrm{F}_{1}-\mathrm{F}_{9}\right)$ are presented in Table 5.

The polynomial equation for the $3^{2}$ full factorial design was as follows:

$\mathrm{Y}=\mathrm{b}_{0}+\mathrm{b}_{1} \mathrm{X}_{1}+\mathrm{b}_{2} \mathrm{X}_{2}+\mathrm{b}_{12} \mathrm{X}_{1} \mathrm{X}_{2}+\mathrm{b}_{11} \mathrm{X}_{1}^{2}+\mathrm{b}_{22} \mathrm{X}_{2}^{2} \cdots$

$Y$ - dependent variable, $b_{0}-$ mean response of 9 trials, $b_{1}$ estimated coefficient for $X_{1}, b_{2}$-estimated coefficient for $X_{2^{\prime}}$ $\mathrm{b}_{12}$ - interaction term, $\mathrm{X}_{1}{ }^{2}$ and $\mathrm{X}_{2}{ }^{2}$ - coefficients for nonlinearity. Validity of the derived equations was evaluated by formulating 2 counter check batches of intermediate quantities $\left(C_{1}, C_{2}\right)$.

\section{Table 1. Experimental design layout}

\begin{tabular}{|c|c|c|c|c|c|c|c|c|c|c|c|}
\hline \multirow{2}{*}{$\begin{array}{l}\text { Name of } \\
\text { ingredients }\end{array}$} & \multicolumn{11}{|c|}{ Experimental design } \\
\hline & $F_{1}$ & $\mathrm{~F}_{2}$ & $\mathrm{~F}_{3}$ & $\mathrm{~F}_{4}$ & $\mathrm{~F}_{5}$ & $\mathrm{~F}_{6}$ & $\mathrm{~F}_{7}$ & $\mathrm{~F}_{8}$ & $\mathrm{~F}_{9}$ & $C_{1}$ & $\mathrm{C}_{2}$ \\
\hline$X_{1}$ & 1 & 1 & 1 & 0 & 0 & 0 & -1 & -1 & -1 & -0.5 & +0.5 \\
\hline$x_{2}$ & 1 & 0 & -1 & 1 & 0 & -1 & 1 & 0 & -1 & -0.5 & +0.5 \\
\hline
\end{tabular}

Table 2. Formulation of SR pravastatin tablets

\begin{tabular}{lccccccccc}
\multirow{2}{*}{$\begin{array}{l}\text { Name of } \\
\text { ingredients }\end{array}$} & \multicolumn{7}{l}{ Quantity of ingredients per tablet (mg) } \\
\cline { 2 - 10 } & $\mathrm{F}_{1}$ & $\mathrm{~F}_{2}$ & $\mathrm{~F}_{3}$ & $\mathrm{~F}_{4}$ & $\mathrm{~F}_{5}$ & $\mathrm{~F}_{6}$ & $\mathrm{~F}_{7}$ & $\mathrm{~F}_{8}$ & $\mathrm{~F}_{9}$ \\
\hline Pravastatin & 40 & 40 & 40 & 40 & 40 & 40 & 40 & 40 & 40 \\
\hline HPMC K4M & 35 & 35 & 35 & 25 & 25 & 25 & 15 & 15 & 15 \\
\hline SCMC & 35 & 25 & 15 & 35 & 25 & 15 & 35 & 25 & 15 \\
\hline Lactose & 82 & 92 & 102 & 92 & 102 & 112 & 102 & 112 & 122 \\
\hline Talc & 4 & 4 & 4 & 4 & 4 & 4 & 4 & 4 & 4 \\
\hline $\begin{array}{l}\text { Magnesium } \\
\text { stearate }\end{array}$ & 4 & 4 & 4 & 4 & 4 & 4 & 4 & 4 & 4 \\
\hline
\end{tabular}

Total weight $200 \quad 200 \quad 200 \quad 200 \quad 200 \quad 200 \quad 200 \quad 200 \quad 200$

SR: Sustained release, HPMC: Hydroxy methyl propyl cellulose, SCMC: Sodium carboxy methyl cellulose 
The equations for dependant variables developed as mentioned below,

$Y_{1}=0.514-0.012 X_{1}-0.094 X_{2}-0.038 X_{1} X_{2}+0.055 X_{1}^{2}+0.0171 X_{2}^{2}\left(\right.$ for $\left.t_{10 \%}\right)$

$Y_{2}=3.393-0.078 X_{1}-0.612 X_{2}-0.250 X_{1} X_{2}+0.363 X_{1}^{2}+0.112 X_{2}^{2}\left(\right.$ for $t_{50 \%}$ )

$Y_{3}=6.79-0.155 X_{1}-1.222 X_{2}-0.507 X_{1} X_{2}+0.722 X_{1}^{2}-0.225 X_{2}^{2}\left(\right.$ for $t_{75 \%}$ )

$Y_{4}=11.280-0.260 X_{1}-2.01 X_{2}-0.840 X_{1} X_{2}+1.21 X_{1}^{2}+0.371 X_{2}^{2}\left(\right.$ for $\left.t_{90 \%}\right)$

Batch $\left(F_{5}\right)$ is the identical product

The +ve sign for the coefficient of $X_{1}$ in $Y_{1}, Y_{2}, Y_{3}$, and $Y_{4}$ signifies that as the amount of $X_{1}$ increases all independent variable values also increase. In other words the data demonstrate that both $X_{1}$ and $X_{2}$ affect $t_{10 \%}, t_{50 \%}, t_{75 \%}$, and $t_{90 \%}$. From the results it can be concluded that an increase in the amount of polymer leads to a decrease in release rate of the drug and the drug release pattern may be altered by changing the quantities of $X_{1}$ and $X_{2}$ to appropriate levels. The dissolution parameters predicted from the polynomial equations and those actually observed from the experimental results are summarized in Table 6. Closeness of results was seen between actual values and predicted values. This proves that the polynomial equation developed was valid and confirms the validity of the derived equations. The response surface/surface morphological plots were presented to show the effects of $X_{1}$ and $X_{2}$ on dependent variables The final best (optimized, based on desirability factor above 0.999) formulation $\left(F_{5}\right)$ is an identical product showing a similarity factor $\left(f_{2}\right)$ of 89.559 , difference factor $\left(f_{1}\right)$ of 1.546 , and $t_{c a l}$ is $<0.05$ when compared with the marketed product (Pravachol).

\section{CONCLUSION}

The current research work focused on the utility of macromolecules (polymers) such as HPMC K4M and SCMC in the formulation of SR tablets for pravastatin using a $3^{2}$ factorial design. The results revealed that the amount of polymers was inversely proportional to the rate of drug release from the formulation. Utilization of polymers in the formulation was beneficial for obtaining prolonged release of the active moiety. Formulation $F_{5}$ follows zero order release and a non-Fickian diffusion mechanism. $F_{5}$ may be administered for the effective management of hypercholesterolemia and atherosclerotic vascular disease and to reduce the risk of cardiovascular disease. The best formulation shows good retaining

Table 3. Final product quality assurance parameters

\begin{tabular}{lllllll} 
S.no. & Formulation code & Hardness $\left(\mathrm{kg} / \mathrm{cm}^{2}\right)$ & Thickness $(\mathrm{mm})$ & Friability $(\%)$ & $\%$ Weight variation & Drug content $(\%)$ \\
\hline 1 & $F_{1}$ & $3.52 \pm 0.1$ & $2.76 \pm 0.12$ & $0.28 \pm 0.02$ & $200.3 \pm 0.12$ & $99.23 \pm 0.27$ \\
\hline 2 & $F_{2}$ & $3.47 \pm 0.3$ & $2.86 \pm 0.14$ & $0.25 \pm 0.022$ & $199.72 \pm 0.28$ & $98.36 \pm 0.64$ \\
\hline 3 & $F_{3}$ & $4.10 \pm 0.5$ & $2.76 \pm 0.12$ & $0.41 \pm 0.04$ & $199.2 \pm 0.31$ & $98.53 \pm 0.37$ \\
\hline 4 & $F_{4}$ & $3.79 \pm 0.2$ & $2.64 \pm 0.16$ & $0.38 \pm 0.022$ & $199.51 \pm 0.45$ & $99.46 \pm 0.44$ \\
\hline 5 & $F_{5}$ & $4.05 \pm 0.5$ & $2.68 \pm 0.12$ & $0.35 \pm 0.05$ & $201.0 \pm 0.19$ & $99.40 \pm 0.300$ \\
\hline 6 & $F_{6}$ & $3.88 \pm 0.20$ & $2.54 \pm 0.26$ & $0.22 \pm 0.027$ & $202.1 \pm 0.14$ & $99.65 \pm 0.35$ \\
\hline 7 & $F_{7}$ & $3.50 \pm 0.40$ & $2.56 \pm 0.14$ & $0.51 \pm 0.04$ & $200.6 \pm 0.14$ & $99.23 \pm 0.32$ \\
\hline 8 & $F_{8}$ & $4.05 \pm 0.20$ & $2.54 \pm 0.16$ & $0.48 \pm 0.02$ & $201.1 \pm 0.19$ & $99.59 \pm 0.31$ \\
\hline 9 & $F_{9}$ & $3.85 \pm 0.5$ & $2.45 \pm 0.15$ & $0.23 \pm 0.027$ & $199.6 \pm 0.28$ & $98.47 \pm 0.43$
\end{tabular}

Table 4. Regression analysis for factorial trials

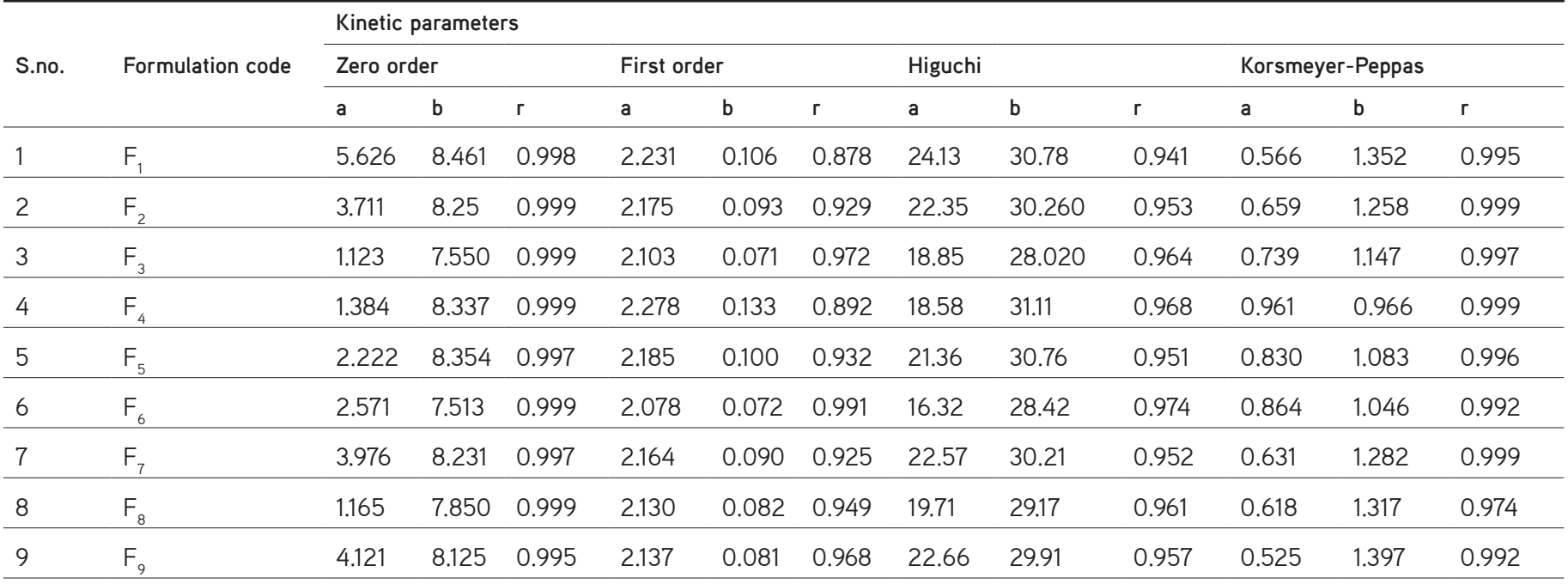

a: Intercept, b: Slope, r: Correlation coefficient 


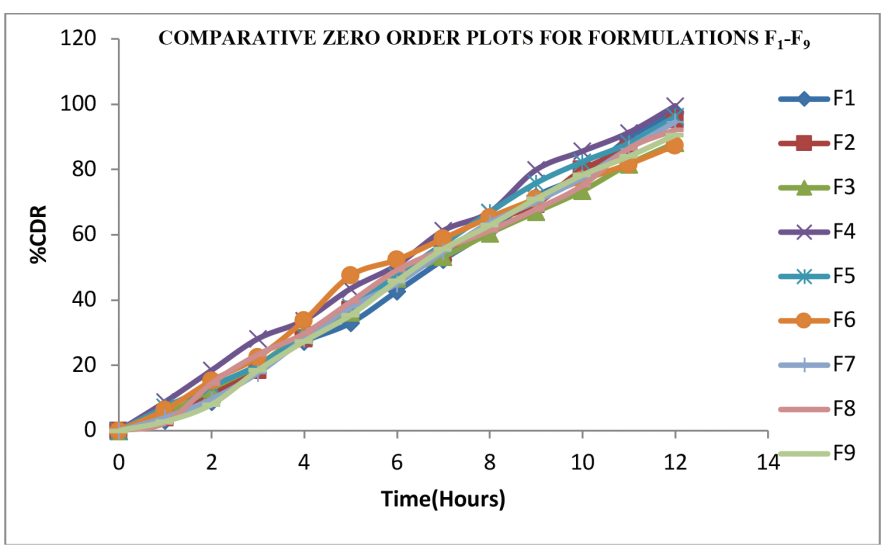

Figure 1. Comparative zero order plots

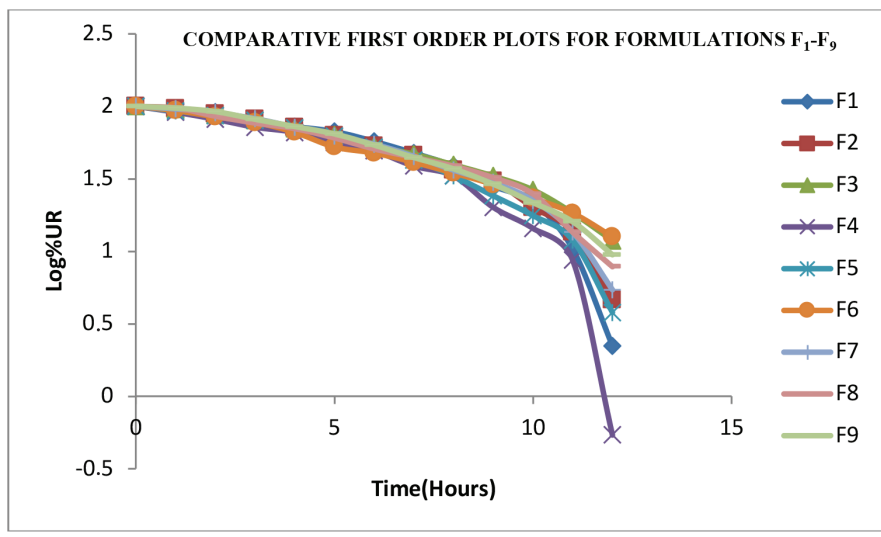

Figure 2. Comparative first order plots

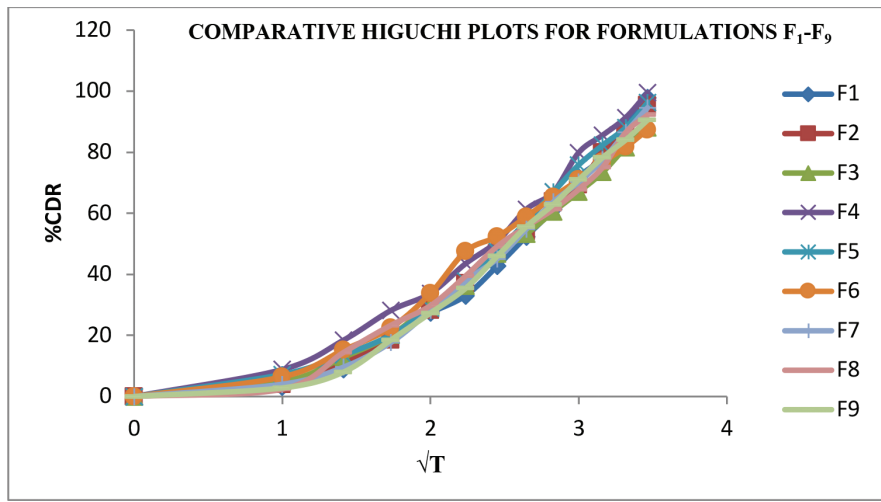

Figure 3. Comparative Higuchi plots

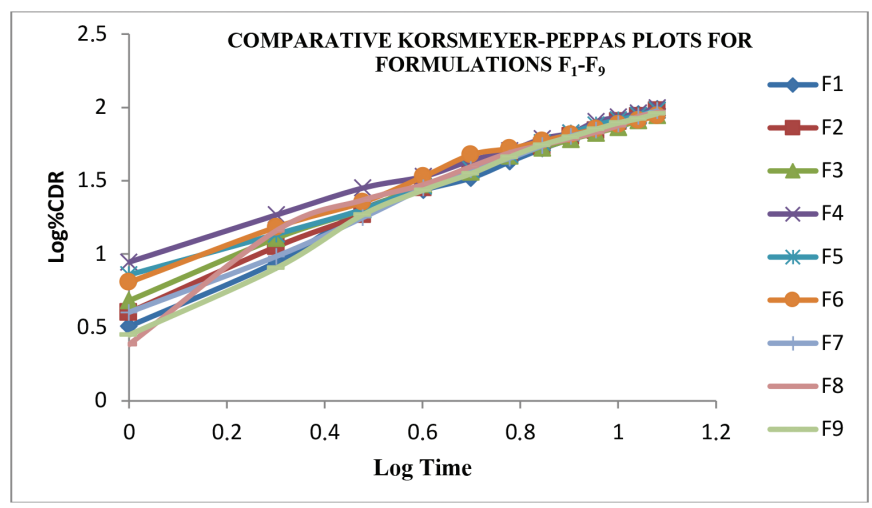

Figure 4. Comparative Korsmeyer-Peppas plots
Response Surface Plot for $\mathbf{t} 10 \%$

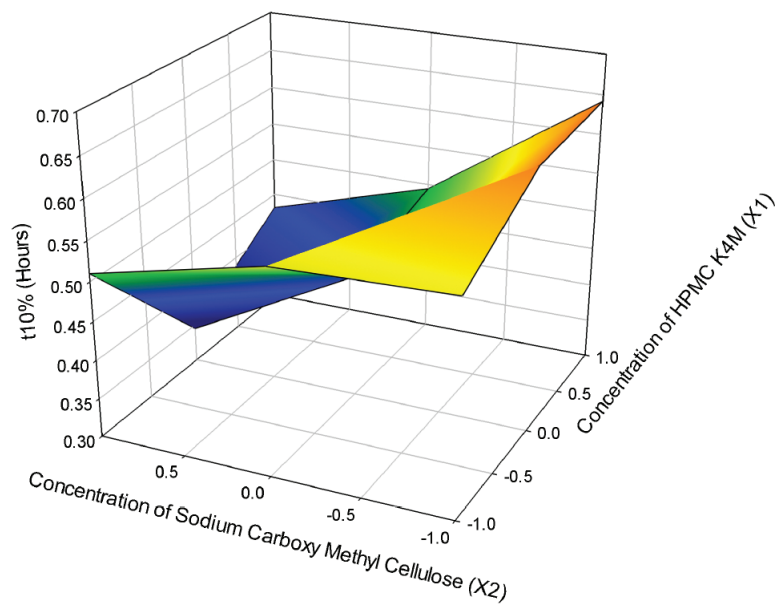

Figure 5. Response surface plots for $\mathrm{t} 10 \%$

t: Time taken to release

Response Surface Plot for $t 50 \%$

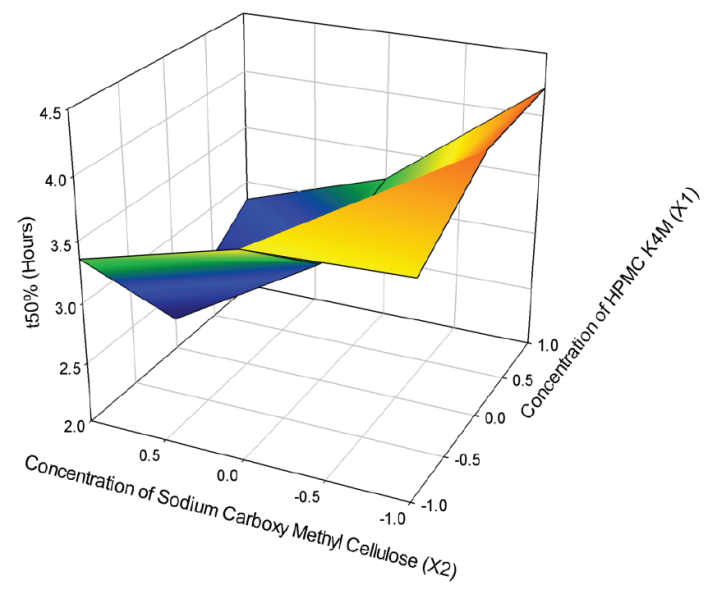

Figure 6. Response surface plots for $t 50 \%$

HPMC: Hydroxy methyl propyl cellulose Response Surface Plot for $\mathrm{t} 75 \%$

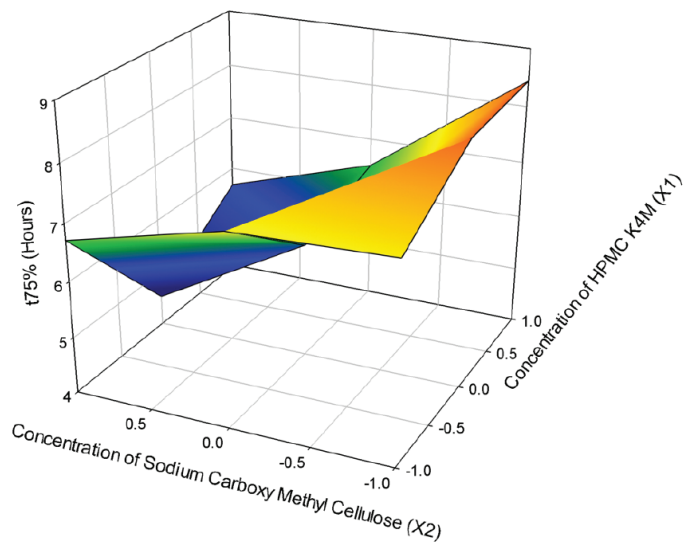

Figure 7. Response surface plots for $t 75 \%$ t: Time taken to release 
Response Surface Plot for $190 \%$

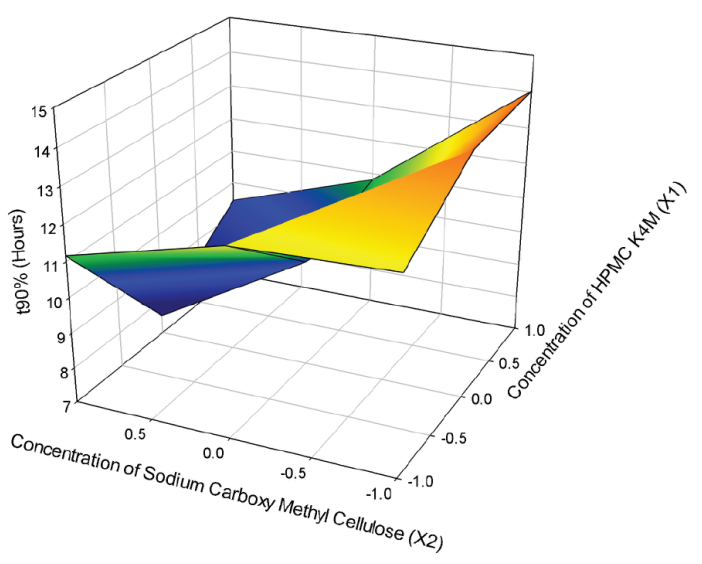

Figure 8. Response surface plots for $190 \%$

\section{Table 5. Dissolution parameters of SR pravastatin tablets}

\begin{tabular}{llllll} 
S.no. & Formulation code & \multicolumn{4}{l}{ Kinetic parameters } \\
\cline { 3 - 6 } & & $\mathrm{t}_{10 \%(\mathrm{~h})}$ & $\mathrm{t}_{50 \%(\mathrm{~h})}$ & $\mathrm{t}_{75 \%(\mathrm{~h})}$ & $\mathrm{t}_{90 \%(\mathrm{~h})}$ \\
\hline 1 & $\mathrm{~F}_{1}$ & 0.431 & 2.837 & 5.671 & 9.423 \\
\hline 2 & $\mathrm{~F}_{2}$ & 0.493 & 3.253 & 6.521 & 10.81 \\
\hline 3 & $\mathrm{~F}_{3}$ & 0.646 & 4.225 & 8.449 & 14.01 \\
\hline 4 & $\mathrm{~F}_{4}$ & 0.352 & 2.267 & 4.539 & 7.529 \\
\hline 5 & $\mathrm{~F}_{5}$ & 0.459 & 3.025 & 6.040 & 10.045 \\
\hline 6 & $\mathrm{~F}_{6}$ & 0.637 & 4.181 & 8.341 & 13.859 \\
\hline 7 & $F_{7}$ & 0.511 & 3.361 & 6.718 & 11.120 \\
\hline 8 & $\mathrm{~F}_{8}$ & 0.564 & 3.694 & 7.383 & 12.252 \\
\hline 9 & $\mathrm{~F}_{9}$ & 0.561 & 3.735 & 7.469 & 12.411 \\
\hline
\end{tabular}

t: Time taken to release, SR: Sustained release

Table 6. Kinetic parameters for counter check formulations

Formulation Predicted value Actual observed value

code

\begin{tabular}{lllllllll}
\hline & $t_{10 \%(h)}$ & $t_{50 \%(h)}$ & $t_{75 \%(h)}$ & $t_{90 \%(h)}$ & $t_{10 \%(h)}$ & $t_{50 \%(h)}$ & $t_{75 \%(h)}$ & $t_{90 \%(h)}$ \\
\hline$C_{1}$ & 0.579 & 3.790 & 7.591 & 12.610 & 0.582 & 3.785 & 7.597 & 12.585 \\
\hline$C_{2}$ & 0.473 & 3.101 & 6.212 & 10.317 & 0.477 & 3.107 & 6.215 & 10.313 \\
\hline
\end{tabular}

characteristics. It also avoids the first pass effect, which will ultimately improve the clinical response.

\section{ACKNOWLEDGEMENTS}

The author would like to thank the Management \& Staff of MAM College of Pharmacy, Kesanupalli, Narasaraopet, Guntur, Andhra Pradesh, India for providing support for successful completion of the research study.

Conflicts of interest: No conflict of interest was declared by the authors. The authors alone are responsible for the content and writing of the paper.

\section{REFERENCES}

1. Gunda RK, Kumar JNS, Babu CA, Anjaneyulu MV. Formulation development and evaluation of lamotrigine sustained release tablets using $3^{2}$ factorial design. Int J Pharm Sci Res. 2015;6:1746-1752.

2. Bankar GS, Rhodes CT. Eds. Sustained and controlled drug delivery system. Modern Pharmaceutics (3rd ed). New York; Marcel Dekker Inc; 1996:668-669.

3. Lachmann L, Lieberman HA, Kanig JL. Sustained release dosage forms. The Theory \& Practice of Industrial Pharmacy (3rd ed). Bombay; Varghese Publishing House; 1991:430-441.

4. Gunda RK. Formulation development and evaluation of rosiglitazone maleate sustained release tablets using $3^{2}$ factorial design. Int J Pharm Tech Res. 2015;8:713-724.

5. Prakash P, Porwal M, Saxena A. Role of natural polymers in sustained release drug delivery system: application and recent approaches. Int Res J Pharmacy. 2011;2:6-11.

6. Rhodes $\mathrm{CT}$, Robinson JR. Sustained and controlled drug delivery system. Modern Pharmaceutics (4th ed). New York; Marcel Dekker Inc; 2003:503-505.

7. Garg Y, Pathak K. Design and in vitro performance evaluation of purified microparticles of pravastatin sodium for intestinal delivery. AAPS Pharm Sci Tech. 2011;12:673-682.

8. Nilesh K, Komal JC, Abhijeet SK. Formulation and evaluation of self emulsifying drug delivery system of pravastatin sodium. Int $\mathrm{J}$ Inn Pharm Sci Res. 2015;3:527-550.

9. Maurya SK, Bali V, Pathak K. Bilayered transmucosal drug delivery system of pravastatin sodium: statistical optimization, in vitro, ex vivo, in vivo and stability assessment. Drug Delivery. 2012;19:45-57.

10. Shidhaye SS, Thakkar PV, Dand NM, Kadam VJ. Buccal drug delivery of pravastatin sodium. AAPS PharmSci Tech. 2010;11:416-424.

11. Boyong LI, Nangia A, Dely A, Wong D. Stable pharmaceutical compositions containing pravastatin. WO Patent. 03/000239; 2003.

12. Ramanathan A, Sreeja Sreekumar G. Development of chronomodulated drug delivery system of pravastatin sodium for the treatment of hypercholesterolemia. Der Pharm Sin. 2014;5:36-41.

13. Kapse Vidya N, Chemate SZ, Dharashive VM. Formulation development and solubility enhancement of rosuvastatin calcium tablet prepared by complexation with $\beta$-cyclodextrin by kneading method. Int J Pharm Sci Res. 2016;7:4882-4892.

14. Puttegowda VD, Karki R, Goli D, Jha SK, Mudagal MP. Formulation and pharmacokinetic evaluation of microcapsules containing pravastatin sodium using rats. Scientifica (Cairo). 2016;7623193.

15. Kumar JNS, Gunda RK. Design, formulation and evaluation of pravastatin fast dissolving tablets. Pharm Met. 2018;9:16-23.

16. Shende MA, Marathe RP, Khetmalas SB, Dhabale PN. Studies on development of sustained release diltiazem hydrochloride matrices through jackfruit mucilage. Int J Pharm Pharm Sci. 2014;6:72-78.

17. Schwartz JB, O'Connor RE. Optimization techniques in pharmaceutical formulation and processing. Drug Pharm Sci. 1996;72:727-752.

18. Gunda RK, Kumar SJN. Formulation development and evaluation of zidovudine sustained release tablets using $3^{2}$ factorial design. Der Pharm Sin. 2015,6:59-67. 
19. Kharia AA, Hiremath SN, Singhai K, Omray K, Jain K. Design and optimization of floating drug delivery system of acyclovir. Indian $\mathrm{J}$ Pharm Sci. 2010;72:599-606.

20. Gunda RK, Manchineni PR, Dhachinamoorthi D. Design, development, and in vitro evaluation of sustained release tablet formulations of olmesartan medoxomil. MOJ Drug Des Develop Ther. 2018;2:164-169.

21. Gunda RK, Manchineni PR, Thangavel V. A statistical study on the formulation development of sustained release tablets for valsartan sodium. MOJ Drug Des Develop Ther. 2018;2:217-222.
22. Higuchi T. Mechanism of sustained-action medication. Theoretical analysis of rate of release of solid drugs dispersed in solid matrices. $J$ Pharm Sci. 1963;51:1145-1149.

23. Peppas NA. Analysis of Fickian and non-Fickian drug release from polymers. Pharm Acta Helv. 1985;60:110-111.

24. Dortunc B, Gunal N. Release of acetazolamide from swellable HPMC matrix tablets. Drug Dev Ind Pharm. 1997;23:1245-1249. 